\title{
RETÓRICA E FAKE NEWS: UMA ANÁLISE DA MENTIRA COMO MEIO DE PERSUASÃO
}

\author{
RHETORIC AND FAKE NEWS: AN ANALYSIS OF LYING AS A MEANS OF \\ PERSUASION
}

João Eudes Rocha De Jesus ${ }^{1}$

\section{RESUMO}

Neste artigo, propomos compreender como o processo retórico de construção da mentira acontece a partir das fake news. Para tal, realizamos uma pesquisa bibliográfica sobre alguns pontos da Retórica de Aristóteles e Perelman, e de outras áreas do conhecimento que trataram da questão da mentira e das fake news. A utilização da mentira como meio de persuasão é uma forma de manipulação e tem o seu poder reforçado, a partir do uso das tecnologias de informação e comunicação. O contexto de desordem informacional em que nos encontramos, favorece a divulgação de fake news. Compreender como ocorre o processo retórico da construção de mentiras (fake news) oferece-nos pistas sobre a forma como podemos enfrentar e lidar com o problema.

Palavras-chave: Retórica, mentira, fake news, persuasão, manipulação.

\begin{abstract}
In this paper, we propose to understand how the rhetorical process of lie construction happens from the fake news. To do so, we undertook a bibliographical research about some points of Aristotle and Perelman's Rhetoric, and other areas of knowledge that have dealt with the issue of lies and fake news. The use of lies as a means of persuasion is a shape of manipulation and has its power enhanced employing information and communication technologies. The context of informational disorder in which we find ourselves favors the dissemination of fake news. Understanding how the rhetorical process of the construction of lies (fake news) takes place offers us clues as to how we can face and deal with the problem.
\end{abstract}

Keywords: Rhetoric, lie, fake news, persuasion, manipulation.

\footnotetext{
${ }^{1}$ Doutor em Filosofia pela Pontificia Università Gregoriana (Roma/Itália, 2006). Mestre em Filosofia pela Pontificia Università Gregoriana (Roma/Itália, 2003). Bacharel em Teologia pela Universidade Católica do Salvador (Curso Livre, 1991). Licenciatura em Pedagogia pela Universidade do Estado da Bahia (1997). Bacharel em Teologia pela Faculdade Católica de Fortaleza (2010). Bacharel em Filosofia pela Universidade do Sul de Santa Catarina (2011). Afiliação: Professor da Faculdade Anísio Teixeira, Feira de Santana (BA) e Faculdade Católica de Feira de Santana, Feira de Santana (BA). LATTES: http://lattes.cnpq.br/4164422161941001. ORCID: https://orcid.org/0000-0002-2169-9119. E-MAIL: jotaeudes@gmail.com .
} 


\section{INTRODUÇÃO}

A mentira consiste no esforço argumentativo comunicativo por parte do emissor em fazer com que o seu interlocutor aceite uma proposição falsa como verdadeira. A temática não é nova, pois acompanha a humanidade desde sua origem. Objeto de estudo em questão pode ser tratado a partir de variados aspectos: moral, religioso, linguístico, psicológico, jurídico, sociológico e político, mas o que nos interessa nesse trabalho é tratarmos da mentira em uma das suas modalidades que são as fake news.

A questão das fake news não é uma novidade, pois as divulgações de notícias falsas, boatos e desinformações com a intenção de enganar, legitimar uma visão de mundo, um ponto de vista política, alcançar algum objetivo financeiro, ou mesmo prejudicar pessoas ou grupos, são acontecimentos recorrentes na história. As consequências são sempre desastrosas, pois alguém em particular ou a sociedade sai prejudicada.

Em nossos dias, a temática ganha relevância por conta do advento das novas tecnologias de informação e comunicação, bem como pela popularização das redes sociais que amplificam e potencializam o poder de influência das fake news. O problema das fake news, nos últimos anos, se apresenta como um dos assuntos que desperta o interesse de pesquisadores das áreas da linguística, da semiótica, da comunicação, da sociologia, do direito e da filosofia.

O que se constata imediatamente é que a disseminação das fake news traz consigo graves consequências para indivíduos, instituições e se constitui como uma ameaça perigosa à construção da democracia. Daí a necessidade de conhecermos como esta se estrutura para assim podermos nos precaver dos seus ardis.

O objetivo do nosso artigo é compreender como se dá o processo retórico da construção da mentira a partir das fake news. Por analogia, podemos afirmar: se conhecemos o veneno, podemos obter seu antídoto. Para nós, este antídoto, é a retórica.

O presente texto foi construído a partir de uma pesquisa bibliográfica tendo como referência alguns pontos da Retórica de Aristóteles, de Perelman e de outras áreas do conhecimento que se ocuparam sobre a questão da mentira e das fake news.

Em vista de compreendermos como se dá o processo retórico de construção da mentira a partir das fake news, dividimos nosso trabalho em três momentos. No primeiro, faremos a distinção necessária entre persuadir e manipular, procurando caracterizar como se dá o processo de manipulação. No segundo momento, veremos como se dá a construção da mentira, ou seja, como se dá o processo de manipulação partir das fake news, e, por fim, apresentaremos algumas estratégias de persuasão utilizadas pelo mentiroso (orador) na construção do seu discurso. 


\section{A MENTIRA (FAKE NEWS) COMO MEIO DE PERSUASÃO}

A mentira é uma forma de persuasão, pois quem mente opera um grande esforço para que o seu interlocutor aceite uma afirmação falsa como verdadeira. O mentiroso para alcançar seu objetivo se valerá conscientemente ou inconsciente de estratégias de manipulação (DERRIDA, 1996). Para compreendermos melhor a questão, faz-se necessário que busquemos entender como se dá o processo persuasivo em que se fundamenta a mentira.

A história testemunha que o recurso à mentira como meio de persuasão é algo recorrente no desenrolar do tempo. O expediente da mentira serviu de pressuposto para justificar conflitos, guerras, caça às bruxas na Idade Média, perseguição aos judeus, influenciou eleições de papas, acirrou a hostilidade entre religiões, conduziu uma rainha à guilhotina, sustentou ditaduras, depôs e elegeu governantes, legitimou golpes que mudaram o rumo dos acontecimentos ${ }^{1}$. Em nossos dias, a problemática da mentira se torna evidente a partir do fenômeno das fake news e das consequências que delas decorrem.

O recurso à mentira, expresso a partir das fake news como meio de persuasão, foi, desde sempre, atrelado à questão do poder e suas estratégias de domínio. Sobre isso, Derrida (1996, p. 11) em um momento do seu texto História da mentira: prolegômenos, referir-se-á a Hannah Arendt ${ }^{2}$ que afirmava: "as mentiras sempre foram consideradas instrumentos necessários e legítimos, não só para os políticos ou demagogos, mas também ao estadista”. Ainda de acordo com este autor, não podemos esquecer que em nossa época a mentira se constituiu como a principal arma de persuasão dos regimes autoritários e totalitários (DERRIDA, 1996, p. 26). Como exemplo, podemos recordar o uso da propaganda como suporte para o estado nazista.

A temática da mentira, em nossos dias, ganha relevância a partir do fenômeno das fake news que se disseminam de modo rápido e descontrolado, com grande poder de influência sobre o modo de pensar e agir das pessoas. $\mathrm{O}$ uso das fake news se traduzem não somente em mentiras, mas também em boatos e desinformações, e têm se tornado uma poderosa ferramenta de comunicação política a serviço daqueles que almejam influenciar a opinião pública, alcançar o poder político e nele se manter.

O uso das fake news, da mentira, como ferramenta, é uma ameaça para democracia, pois estas ao se imporem como narrativa no âmbito da política conseguem de influir no processo eleitoral e nos processos decisórios que envolvem a vida da sociedade e dos seus cidadãos. A consolidação da democracia, do Estado Democrático de Direito depende, intrinsecamente, da participação ativa dos cidadãos, seja por atuação direta ou através de seus representantes eleitos. A construção saudável de um projeto de sociedade demanda que decisões importantes não podem estar 
fundamentadas em premissas falsas, pois nãose poderia, de antemão, prever a conclusão que decorreria das mesmas.

O recurso à mentira, às fake news como instrumento político é incompatível com os princípios democráticos da transparência, clareza, objetividade e veracidade das informações (AGLANTZAKIS, 2020). A participação na democracia implica no debate, no conflito, no contraditório em vista da tomada de uma decisão importante para toda sociedade a partir do consenso. Não é possível tomar decisões acertadas tendo por base aquilo que não corresponde à realidade, dados e fatos.

A busca da verdade ou da veracidade é a condição necessária para concretizarmos o bem comum em uma sociedade e para construção de uma sociedade democrática. Neste sentido, a informação clara, objetiva e transparente, e acessível a todos é determinante para que os membros da sociedade possam participar, pertinentemente, das decisões que lhes são importantes. Sobre esta questão nos adverte Lafer:

\begin{abstract}
A verdade factual não é questão de opinião. Por isso mesmo a democracia, que pressupõe o respeito pela cidadania, o controle e a responsabilidade do poder, requer o direito dos governados a uma informação exata e honesta. A palavra dos governantes que máscara e esconde põe em questão o chão da vida política democrática dada pela verdade factual. Diante do camaleonismo das "versões", leva à apatia, ao cinismo, à indiferença que minam a confiança exigida pela democracia (1995 n.p.)
\end{abstract}

A participação na democracia implica no debate entre discursos em um ambiente pluralista, implicando sobretudo no uso da palavra em vista de alcançar um consenso respaldado em bases racionais (HABERMAS, 2003). De acordo Habermas, a legitimidade das decisões, em um contexto democrático, depende de procedimentos que promovam a participação de todos em condições de igualdade e se paute sobre o que é racional e aceitável (HABERMAS, 2003). Sob tal perspectiva, inferimos que a mentira se constitui como um simulacro de racionalidade, onde o que é falso pode se passar como veraz, capaz de inferir nas decisões em uma conjuntura democrática. Em suma, a mentira como ferramenta política, é uma verdadeira ameaça à democracia.

A mentira enquanto uma construção argumentativa que falsifica intencionalmente os fatos, conceitos e teorias para que os receptores não se deem conta de que estão sendo enganados. Para alcançar tal intento, o orador vale-se do instrumental da lógica, dos princípios da demonstrabilidade, da objetividade e da veracidade, pois se a mentira não for bem construída, não logrará êxito no seu intento de enganar seus destinatários (MENDONÇA, 2012, p. 27). Observamos que uso da mentira como ferramenta política se torna um problema que precisa ser compreendido em vista da sua superação: é o que nos propomos a fazer na parte que vem a seguir. 


\section{A MENTIRA: UMA FORMA ILEGÍTIMA DE PERSUASÃO}

A mentira é uma forma ilegítima de persuasão, pois além de ferir os princípios éticos das relações interpessoais, no âmbito político-social, constitui-se como um modo de manipulação inconciliável com os fundamentos de uma sociedade democrática. Quando nos referimos à persuasão, fazemos de imediato a alusão à Retórica, visto que esta se caracteriza como a arte de persuadir. Mas, qual seria a relação entre Retórica e mentira? A Retórica estaria à serviço da mentira? De que modo a Retórica nos ajuda a compreender a mentira e as estratégias persuasivas que lhes são pertinentes?

De antemão, defendemos que a Retórica não está a serviço da mentira, mas os seus pressupostos nos permitem entender como se dá estratégia persuasiva utilizada pelo mentiroso (orador) na construção do seu discurso. Convém destacar, previamente, que não podemos confundir persuasão com manipulação, pois embora estas se movam pelo mesmo objetivo que é o de conquistar o interlocutor, fazendo-o aceitar uma determinada tese, estas se diferenciam a partir da intencionalidade do orador. Cumpre-nos deixar claro que a persuasão visa à verdade, e a manipulação visa enganar, ludibriar. Adiante esclareceremos estes pontos quando tratarmos da Retórica e seu objetivo.

A Retórica, de acordo com Aristóteles (Retórica I, 1, 1355a 20-31), se constitui como um modo de dizer a verdade adequado a determinados temas e determinadas categorias de auditórios, de um modo tal que nem mesmo as ciências exatas com todas as suas evidências são capazes de demonstrar. A Retórica objetiva "descobrir o que é adequado para persuadir", visa encontrar a melhor maneira de dizer e comunicar uma verdade de modo a obter a adesão do receptor à tese apresentada (ARISTÓTELES, Retórica I, 2, 1355 b, 30-34).

A persuasão na perspectiva aristotélica, consiste em "um tipo de demonstração (visto que que nos sentimos o mais plenamente persuadidos quando julgamos que uma coisa foi demonstrada)" (ARISTÓTELES, Retórica I, 1, 1355 a5). Ainda de acordo com Aristóteles, "a persuasão é obtida através do próprio discurso quando demonstramos a verdade, ou o que parece ser verdade, graças à argumentação persuasiva apropriada ao caso em pauta" (Retórica I, 2, 1356 a19-20). A Retórica está intrinsecamente relacionada à verdade, pois os seres humanos a ela, naturalmente, se inclinam (ARISTÓTELES, Retórica I, 1, 1355a 15). O objetivo da Retórica, portanto, não é mentir ou enganar, mas conduzir o interlocutor ao conhecimento da verdade. 
a retórica é útil é porque o verdadeiro e o justo têm naturalmente mais valor que seus opostos. O resultado é que se os julgamentos não forem proferidos como devem ser, o verdadeiro e o justo estarão necessariamente comprometidos, resultado censurável a ser atribuído aos próprios oradores (ARISTÓTELES, Retórica I, 1, 1355a 25).

Como vimos, a Retórica visa à verdade, o verossímil, no entanto, nos alerta Aristóteles, há a possibilidade de alguém inescrupuloso fazer desta um mau uso, o que pode trazer como resultado "grandes danos" (Retórica, I, 1 1355b 5). O mau uso da Retórica constitui-se como uma perversão, uma distorção dos objetivos da persuasão, primando pelo engano, pela dissimulação, pela manipulação induzindo o ouvinte a pensar de uma forma determinada. O mau uso da Retórica consiste em manipular, não em persuadir.

De acordo com Hoffeld Group (2018) a distinção entre persuasão e manipulação pode ser verificada a partir três aspectos: a intenção, a sinceridade em relação ao dizer a verdade e o uso da liberdade. A manipulação se move pela intenção direta de iludir e enganar em vista de obter vantagens e prejudicar. A persuasão, ao contrário, age em função da verdade e em vista do bem do outro. A persuasão prima pela verdade, a manipulação pelo engano e pela mentira. A persuasão respeita a liberdade de escolha do outro, não coage, apenas propõe uma asserção que pode ser aceita desde que seja convincente e razoável, enquanto a manipulação é coercitiva, não respeita a liberdade de escolha alheia.

A mentira está no âmbito da manipulação e se enquadra como um mau uso da Retórica. O mentiroso no seu intento de obter a aquiescência do interlocutor à sua tese, lança mão de todos os meios disponíveis para alcançar seu objetivo. Valer-se-á também das técnicas e estratégias da persuasão, por isso, pensamos ser possível compreender a mentira como estratégia de manipulação a partir de uma análise da retórica sobre este tema.

\section{A CONSTRUÇÃO DA MENTIRA}

A construção de um discurso argumentativo se constitui como um processo comunicativo que envolve três elementos básicos: emissor, mensagem e receptor. Aplicando a Teoria da Comunicação para o campo da Retórica, estes três elementos passam a ser denominados como: orador, discurso e auditório (PERELMAN; TYTECA, 2002). A construção argumentativa de um discurso retórico são os mesmos que encontramos na produção argumentativa da mentira: o mentiroso é o orador, com o seu talento, habilidade e instrumentos para a mentir, a mensagem, é conteúdo por este veiculado, e o auditório é aquele que receberá a mensagem.

No âmbito das fake news, o auditório (o receptor) não apenas acredita na mensagem veiculada pelo orador (o mentiroso), mas a compartilha, colaborando com a disseminação da 
mentira, convertendo-se em um orador, falando para outro auditório. O sucesso do mentiroso na construção do seu discurso dependerá do seu talento e do seu esforço em afirmar uma mentira sem se contradizer.

O orador (mentiroso) para ter êxito a partir do seu discurso, deve ser capaz de enunciá-lo, persuasivamente, mas seu intento não terá sucesso se quem for ouvi-lo não se deixar por este persuadir (MENDONÇA, 2012, p. 67). Neste ponto, se faz necessário trabalharmos a noção de auditório. De acordo com Perelman e Tyteca (2005, p. 20-21), o sucesso do processo argumentativo tem como pré-condição essencial a conquista do auditório em favor da tese do orador.

\subsection{O auditório}

O auditório segundo Perelman e Tyteca (2005, p. 22) não se refere apenas a um conjunto de pessoas para o qual o orador dirige o seu discurso, mas é, antes de tudo, "o conjunto daqueles que o orador quer influenciar com sua argumentação". O principal objetivo do orador é de conseguir a adesão do auditório à sua tese. Para alcançar tal intento, é imprescindível que este tenha um conhecimento adequado do auditório, devendo estudá-lo para poder prever os meios e estratégias de persuasão adequados a fim de conquistá-lo a partir do seu discurso (PERELMAN; TYTECA, 2005, p. 22-29).

A partir da concepção de auditório proposta por Perelman, podemos presumir que o contexto histórico, social e cultural em que se encontram as pessoas é determinante para tecermos considerações acerca dos auditórios nos quais as fake news são veiculadas. No auditório em que são disseminadas as fake news, os ouvintes não somente aquiescem à mensagem do mentiroso (orador), mas também a compartilham com outras pessoas de seu círculo de relação, criando uma cadeia incomensurável intercomunicacional em constante retroalimentação, culminando na falsificação da realidade (AMARAL; SOFIA, 2019).

A capacidade de "viralização" e aceitação das fake news é algo impressionante. Diante do exposto, a pergunta que nos intriga e que responderemos a partir de agora é a seguinte: quem é o auditório do mentiroso (produtor de fake news)? O que leva as pessoas a aquiescerem às fake news?

Quanto a rápida disseminação das fake news, entre tantos outros fatores que podem ser tomados em consideração, podemos presumir que decorra do desenvolvimento e popularização das tecnologias de informação e comunicação. O surgimento destas tecnologias colocou em crise os paradigmas sobre o quais estavam fundados os meios de comunicação tradicionais (LEVY, 1998).

Com o surgimento das novas tecnologias infocomunicacionais, o avanço das redes sociais, o monopólio da verdade e o poder de influência que pertencia à mídia tradicional foi posto em questão. As redes sociais, embora ainda não sejam acessíveis a todos, terminaram por democratizar 
de algum modo o mundo da informação e do conhecimento, antes monopolizado pelos meios de comunicação tradicionais e no mundo técnico e acadêmico. A partir dessa crise, o que constatamos é que não há somente consumidores passivos de conteúdos, mas também produtores que se multiplicam a cada dia (SILVA; OLIVEIRA, 2019).

Com a popularização das redes sociais, por exemplo, observa-se que qualquer pessoa pode ser em simultâneo, consumidora e produtora de conteúdo, podendo influenciar milhares ou milhões, usando recursos simples, acessíveis e baratos. Alguns pesquisadores americanos acreditam que a mídia social se constitui hoje como um quinto poder, com capacidade para desafiar a "autoridade dos três poderes públicos e a imprensa tradicional” (GRANT, 2019, p. 82).

Ainda quanto ao ambiente favorável à disseminação de fake news, Wardle e Derakhshan (2017) constatam que o movimento provocado a partir das novas tecnologias de informação e comunicação e sua popularização, trouxe consigo, afora os benefícios, o fenômeno da desordem informacional. Em escala global, é espantosa a quantidade de informações produzidas, a facilidade e a rapidez na divulgação das mesmas, e, além disso, acessíveis a todos. Diante desta vastidão de conteúdos, torna-se impraticável a verificabilidade da veracidade daquilo que é veiculado.

No universo do mundo virtual marcado pela desordem informacional, o filtro para o discernimento do que é falso ou verdadeiro fica prejudicado. Este é um ambiente fértil para o consumo e a disseminação de fake news, desinformações e más orientações (GRANT, 2019), com um agravante de trazerem consigo o enorme potencial de influência sobre a vida dos indivíduos e da sociedade. O ambiente de desordem de informacional e disseminação descontrolada de fake news abre espaço para o oportunismo dos produtores de fake news que se colocam à serviço da publicidade e da promoção de determinadas ideologias (BAPTISTA, 2020, p. 44).

Outro aspecto favorável à disseminação das fake news diz respeito ao enorme poder de persuasão do orador sobre o auditório potencializada pelo uso dos algoritmos, do suporte de análise de Big-data e o uso de data-analytics. O domínio dos recursos tecnológicos amplificam a capacidade do orador na identificação de sua audiência, permitindo-lhe traçar estratégias para conquistá-la, produzir e distribuir conteúdo sob medida (AMARAL; SOFIA, 2019).

\subsection{A mensagem}

Outro aspecto a ser considerado na construção argumentativa da mentira, diz respeito à mensagem, ao discurso, ao conteúdo a ser veiculado. Esta para ser persuasiva deve corresponder aos interesses do auditório (PERELMAN; TYTECA, 2005, p. 73). Na produção do discurso argumentativo orador deve além de considerar o auditório, deve também estar atento às premissas a serem usadas como ponto de partida para obter o acordo (aquiescência). É essencial saber o que 
o auditório deseja ouvir e qual tese aceitaria (PERELMAN; TYTECA, 2005, p. 73-75). A construção argumentativa da mentira partir das fake news em vista da conquista do seu auditório tem como ponto de partida as premissas que devem ser assimiladas e aceitas pelos ouvintes.

As premissas a partir das quais partem as fake news têm a sua aceitação favorecida por fatores. Entre estes, podemos citar alguns: o excesso de informações, a polarização política, a crise de confiança nas instituições, o individualismo, o imediatismo e o relativismo (LEITE; MATOS, 2017). Em tal contexto, as pessoas são envolvidas de tal forma que terminam assimilando o que lhes é informado, sem o filtro da crítica (LEITE; MATOS, 2017, p. 2337). As pessoas tendem a dar crédito às informações que correspondem aos seus valores e adequadas ao seu modo de pensar e ver o mundo (SEIXAS, 2019).

A partir dessa constatação é que entendemos o porquê da aceitação e aquiescência das pessoas às mensagens com forte apelo às narrativas oportunistas, que distorcem a realidade, que se posicionam a favor de partidos e ideologias políticas, que exploram o medo, o pânico, alimentam estereótipos e preconceitos, que induzem ao ódio e que alimentam o fundamentalismo religioso e político (BAPTISTA, 2020, 44; GREEN, 2004).

Outro aspecto a ser considerado acerca da questão da mensagem veiculada no discurso argumentativo da mentira, refere-se à existência das denominadas bolhas sociais: grupo de pessoas que compartilham os mesmos valores, cultura, gostos, ideologias políticas ou religiosas. Trata-se de um fenômeno que tem sua origem a partir das redes sociais e se potencializa em função dos algoritmos. Em tal ambiente, as pessoas passam vivenciar uma espécie de confinamento, em um circuito fechado e restrito, onde consomem, curtem e compartilham entre si as mesmas mensagens, reforçando e reafirmando, mutuamente, as crenças e valores do grupo ou comunidade a qual pertencem (BARRETO JUNIOR; PELLIZZARI, 2019).

A partir da conjuntura apresentada acima, observa-se que o critério de discernimento para seleção do que verdadeiro ou aceitável, passa a ser o da conveniência pessoal ou o da concordância com o que pensa o grupo ou comunidade a qual pertence (BAPTISTA, 2020, 44). Assim, uma informação será verdadeira se corresponder às crenças políticas, religiosas e ideologia das pessoas em um determinado grupo ou comunidade (SILVA; OLIVEIRA, 2019).

Outra observação é que as redes sociais, a cada dia, têm se tornado a fonte primária de informação para muitas pessoas (MARQUES; VIDIGAL, 2018), criando assim um ambiente favorável à disseminação de fake news. A situação se torna ainda mais grave quando percebemos que as informações veiculadas nas redes sociais podem ser manipuladas e controladas por algoritmos, e divulgadas por web robots (bots) para auditório bem diagnosticado através da data analytics. Tudo isso nos faz perceber dimensão do quanto podemos estar sendo manipulados. 


\subsection{O mentiroso (produtor de fake news)}

A construção do discurso do orador (o mentiroso), em nossos dias, como já vimos acima, é facilitada e otimizada pelas novas tecnologias de informação e comunicação o que potencializa os seus talentos e habilidades na elaboração da sua mensagem. O mentiroso (orador), pode contar com o poder dos algoritmos e web robots (bots) para automatizar a distribuição de conteúdos selecionados, diferenciados. Personalizados e adequados de acordo às características sociais, econômicas, interesses, preferencias e valores de diferenciados auditórios (AMARAL; SOFIA, 2019, p.75; BOZDAG, 2013).

A nova configuração da dinâmica comunicacional e de interações sociais terminam por criar um ambiente favorável à para a propagação das fake news (AMARAL; SOFIA, 2019; LEITE; MATOS 2019. p. 2336). Vivemos na sociedade da informação, são muitos os conteúdos produzidos diariamente, vindos de múltiplas fontes, tornando praticamente impossível ao indivíduo interpretar e refletir sobre cada uma delas (LEITE; MATOS 2019, p. 2336).

$\mathrm{O}$ ambiente de desordem e poluição informacional se constitui como um ambiente favorável a aceitação do discurso dos mentirosos, dado que tal contexto promove a perda de critérios referenciais de objetividade e veracidade que termina por afetar o poder de criticidade das pessoas (LEITE; MATOS 2019. p. 2336- 2337). Favorecido por tal conjuntura e contando com o aparato tecnológico de informação e comunicação disponíveis, o mentiroso (orador) tem a possibilidade de extrapolar o âmbito da simples mentira, ganhando poderes persuasivos inimagináveis.

\section{AS ESTRATÉGIAS PARA A CONSTRUÇÃO DA MENTIRA}

O orador para ter êxito em seu discurso, além de conhecer o auditório e encontrar o meio mais adequado para persuadi-lo, deve também recorrer aos meios e estratégias de persuasão. Aristóteles (Retórica I, 2, 1356a 1-5) apresenta três meios de persuasão que podem ser usados pelo orador em vista de conquistar a adesão do auditório à tese proposta. Estes meios são o ethos, pathos e logos.

O ethos corresponde ao "caráter pessoal do orador", diz respeito à sua imagem diante do auditório. O pathos tem relação com a disposição do auditório em acolher a mensagem do orador, tem a ver com a mobilização das emoções e sentimentos na enunciação do discurso. Por fim, o logos, refere-se ao que se "demonstra ou parece demonstrar", equivale ao discurso lógico, coerente mobilizador da razão (ARISTÓTELES, Retórica I, 2, 1356a 1-20). Um discurso pertinente demanda o uso equilibrado desses três meios de persuasão. 
A construção argumentativa da mentira também se vale dos meios de persuasão para alcançar seu objetivo, pervertendo-os em função da manipulação. O espaço virtual das redes sociais e dos aplicativos de mensagens vai se tornando, cada vez mais, o espaço da Retórica, ou melhor dizendo, na maioria das vezes, pelo seu mau uso. Consciente ou inconscientemente os usuários e produtores de conteúdos se valem dos meios de persuasão aplicada às fake news (GOMES; PENA 2020). Os meios de persuasão no contexto tecnológico informacional e comunicacional se aliam às novas estratégias argumentativas com o objetivo de obter a adesão do auditório.

\subsection{ETHOS}

Ethos é o meio de persuasão a partir do qual orador demonstrar-se-á confiável aos seus interlocutores. De acordo com Aristóteles (Retórica, I, 2, 1356 a 5): “a persuasão é obtida graças ao caráter do orador quando o discurso é proferido de tal maneira que nos faz pensar que o orador é digno de crédito", pois tendemos a acreditar mais depressa nas pessoas em confiamos.

Ainda de acordo com Aristóteles (Retórica, II, 11378 a1, 10), três são as causas tornam um orador persuasivo, a partir do qual este pode até mesmo dispensar a demonstração. Trata-se da prudência, da virtude, e da benevolência. O orador deve aparentar ter todas essas qualidades para apresentar-se como confiável à sua audiência. O uso do ethos como meio de persuasão é fundamental para o sucesso do orador na enunciação do seu discurso, pois sem parecer moralmente integro ou credível, não logrará o êxito desejado.

O ethos no contexto das disseminações das fake news está associado não só às credenciais de credibilidade e competência do orador, mas também é marcado por critérios como simpatia, charme, cortesia de quem comunica a mensagem. (BAPTISTA, 2020, p.46). O ethos, em tal contexto, se manifesta na figura do pseudojornalista, do pseudocientista ou de alguma autoridade anônima. $\mathrm{O}$ ethos também é manifesto naqueles que produzem e compartilham mensagens através por meio das redes sociais e aplicativos: um amigo, familiares, um colega, uma comunidade, ou seja, alguém próximo, cuja autoridade não é colocada em questão.

O ambiente de desordem informacional como já tratamos anteriormente, induz aos indivíduos a dar credibilidade ao que é popular ou que tem relação estreita com o âmbito social onde está inserido. Neste sentido, familiares, amigos e a comunidade se tornam fontes primárias de autoridade (MELIM, at al, 2019; WARDLE E DERAKHSHAN, 2017, p. 49-56). Para alguns, é mais confiável a informação passada por um amigo do que a própria imprensa. Quem compartilha uma fake news, sente-se como um soldado numa batalha, colocando-se na posição de autoridade, garantindo a legitimidade da mensagem veiculada. Tudo isso, nos faz pensar sobre a importância o ethos como meio de persuasão em favor da mentira. 
Ainda sobre o ethos, o ambiente digital traz como novidade o recurso aos hashtags (\#) como meio de persuasão. O hashtag é um meio disponível nas redes sociais que permite que seus usuários possam agrupar conteúdos distribuídos na internet. $\mathrm{O}$ uso de tal recurso também oportuniza agregamento de pessoas em comunidades que compartilham das mesmas crenças e valores. As hashtags funcionam também um agregador de sentidos (RENNÓ; SALLES, 2020).

A partir do uso das hashtags as pessoas podem manifestar sua posição diante de algum assunto, manter-se em contato com outras que se posicionam da mesma forma, reafirmando suas identidades e validando-se entre si (RENNÓ; SALLES, 2020). O agregamento no ambiente cibernético, em alguns momentos, evidenciam que a opinião daqueles que compartilham as crenças e valores, pertinente a um determinado grupo ou comunidade virtual se sobreponha aos fatos e evidências no processo de conhecimento e na formação dos seus pontos de vista (ALZAMORA, 2018, p. 11).

Aquele que compartilha fake news, estando bem ou mal-intencionado, toma para si a autoridade da mensagem veiculada, usurpando a imagem do orador. Desse modo, as fake news vão sendo compartilhadas em acordo com o que diz o ditado popular: "de boca em boca": uma das formas mais poderosas de propaganda, acima de tudo, gratuita (JUCÁ BENTIVEGNA, 2002, PIAZZA; CROCE. 2019 n.p.).

Wardle e Derakhshan (2017, p.7) indicaram que os compartilhamentos online desempenham também uma importante função social, pois, sinaliza aos outros que estamos em concordância e fazemos parte da mesma comunidade. Como seres sociais, sentimos o desejo de estarmos conectados e reconhecidos pelos outros. Tudo isso contribui para a formação do ethos daqueles que se identificam e se validam entre si.

Outra forma de manifestação do ethos se dá por vias não tradicionais da Retórica. Entre este citamos a estética, assim uma notícia, uma informação na internet, pode ser considerada confiável a partir da sua forma de apresentação pictórica ou tipo de designer gráfico utilizado (GOMES; PENNA, 2020 p, 12). Havemos também de considerar a questão da estética presente em algumas fake news. Sob tal perspectiva é possível observar as palavras acompanhadas de imagens que representam desejos e crenças daqueles que compartilham os mesmos valores e se confirmam entre si (SANTAELLA, 2018, p. 91).

Na manipulação, os meios de persuasão não são usados equilibradamente, há sempre o reforço de um ou de outro. As fake news de conteúdo científico, por exemplo, buscam estabelecer a articulação entre ethos e logos, citando uma autoridade ou pseudo-autoridade, valendo-se de jargões científicos, informações e dados estatísticos para aparentar cientificidade, em tal contexto a ênfase no pathos não inspiraria credibilidade (GOMES; PENNA, 2020 p. 8), embora seja possível, em algumas situações, a este meio recorrer. 
Em outros contextos, o ethos se articula com o pathos, pois "as emoções e as crenças pessoais têm grande impacto na formação da percepção que os indivíduos têm do mundo à sua volta" (GOMES; PENNA, 2020 p. 3). A percepção da realidade guiada primordialmente pelas emoções e sentimentos, abstraindo-se dos dados e fatos que a manifesta, gera uma nova realidade, distorcida e enviesada (GOMES; PENNA, 2020 p. 3; MEDRÁN, 2017, p. 33). Assim, a manipulação da relação entre ethos e pathos se apresenta com grande poder persuasivo em benefício do discurso do mentiroso (o orador).

O orador com auxílio da data analytics tem a possibilidade de saber exatamente quem é o seu auditório, podendo assim não somente pensar nos meios e estratégias de persuasão a serem utilizados, bem como, a partir das informações, compor o seu ethos, ajustando sua conduta para corresponder à expectativa dos seus interlocutores. (DURANDIN, 1997, p 126). O orador (mentiroso) está ciente que se não for digno de crédito, não obterá a confiança das pessoas, o que traria um grande prejuízo ao seu discurso.

\subsection{PATHOS}

O pathos é meio de persuasão a partir do qual o orador busca a persuadir o interlocutor valendo-se da sua capacidade de suscitar emoções e sentimentos. De acordo com Aristóteles (Retórica, I, 2, 1356 a), “a persuasão pode ser obtida através dos ouvintes quando o discurso afeta suas emoções; com efeito, os julgamentos que emitimos variam segundo experimentamos sentimentos de angústia, júbilo, amizade ou hostilidade".

Ainda em conformidade com Aristóteles, as emoções são benignas. O problema é quando elas prevalecem, já que bloqueiam o filtro da razão, fazendo as pessoas agirem irracionalmente (GOTTWEIS, 2007, p. 239). O discurso veiculado pelas fake news frequentemente exploram os sentimentos e as emoções do interlocutor provocando uma identificação deste ao conteúdo veiculado, "desencadeando sentimentos que se sobrepõem a razão concorrendo para a aceitação de um discurso, seja ele de um mentiroso ou não” (BAPTISTA, 2020, p. 50).

O discurso veiculado a partir das fake news procura influenciar as crenças e opiniões das pessoas, para tanto vale-se de recursos como o uso de perguntas retóricas, figuras de linguagem, exemplos emocionais, linguajar descritivo, intimidação, aprovação, usa palavreados simples, textos curtos e com títulos atrativos facilmente compreendidas pelo leitor, é comum também o recurso ao humor (BAPTISTA, 2020). O uso de imagens e vídeos são poderosos para operacionalização do pathos, pois, a força pictórica e imagética reforça os textos e estimulam a recepção da mensagem (BERGER; MILKMAN, 2012). 
Como recurso de manipulação, o mentiroso pode valer-se também de supressões, invenções, deformações (DURANDIN, 1997, p. 81), notícias sensacionalistas, polêmicas, narrativas exageradas, uso de título, imagem e pseudônimos para maximizar o poder persuasivo de manipulação. A argumentação centrada no forte apelo à emoção obscurece os problemas, manipulando opiniões e ideias, distorcendo a realidade (BAPTISTA, 2020, p.50).

Os produtores de fake news procuram captar a atenção do leitor para temas importantes, capazes de influenciar suas crenças e opiniões (BAPTISTA, 2020, p.50). A maioria dos compartilhamentos de fake news são movidos por fortes apelos emocionais de raiva e ansiedade. Mobilizadas pelas emoções e sentimentos as pessoas tendem a tomar decisões confiando mais em suas respostas emocionais do que em dados ou fatos (BERGER; MILKMAN, 2012. p.2). No ambiente digital, o pathos encontra reforço nas redes sociais, por conta da proximidade entre as pessoas e da validação social que estas proporcionam (BERGER; MILKMAN, 2012. p.2).

\subsection{LOGOS}

Para Aristóteles (Retórica, I, 2, 1356b 1), o meio de persuasão, por excelência, é o logos, porque envolve o raciocínio lógico e sobre o assunto assim se expressa: "na Retórica, os meios de demonstração real ou demonstração aparente são, tal como na dialética, a indução, o silogismo". A partir do logos o orador demonstrar a verdade através de provas irrefutáveis, evidencias científicas, acontecimentos históricos, dados estatísticos (BAPTISTA, 2020, p. 46). Ainda em conformidade com Aristóteles: “aquilo que é persuasivo o é para alguém, e algo é persuasivo quer porque é de imediato e por si só evidente, quer porque parece ser demonstrado a partir de outras premissas que são elas, persuasivas e convincentes" (Retórica I, 2, 1356 b1 30).

Ainda tratando a respeito do logos, Perelman e Tyteca (2005, p 75-78) defendem que uso de fatos e os dados na construção do discurso se constitui como uma estratégia para obter a adesão do auditório. Orador deve atentar-se que, o recurso aos dados e fatos como meio de persuasão, podem se apresentar como insuficientes para garantir uma demonstração, visto que estes podem ser objeto de questionamentos e colocados sob o crivo da dúvida (MELATI, 2020, p. 193). Para ilustrar o que afirmamos acima, podemos citar a estratégia de manipulação que encontramos alguns grupos e comunidade virtuais organizados (terraplanistas, antiglobalistas e antivacinas. etc.) que se apresentam como autoridade para questionar o estatuto dos fatos já consolidados, semeando a dúvida.

As fake news não se apresentam apenas como notícias falsas, mas também podem ser incluídas nesse rol, a omissão de informações, as mensagens deslocadas do seu contexto, presunções e ilações com a finalidade de ocultar as verdadeiras informações (SEIXAS, 2019 p. 
289; BRETON, 1999, p. 81-82). Ainda no que se refere ao logos a desinformação também faz parte das estratégias de persuasão usadas pelo orador (mentiroso) (RASQUEL, 2019, p.17).

A construção da mentira a partir do logos se caracteriza pelo esforço por parte do orador (mentiroso) em fazer com que o interlocutor acolha uma proposição falsa como verdadeira. $\mathrm{O}$ discurso argumentativo da mentira deve, ao menos, parecer coerente, lógico, sem contradições, dando a impressão de veracidade, sob pena de não ser acolhido pelo interlocutor (MENDONÇA, 2012, p. 66-68). O mentiroso pode aproveitar-se também de premissas verossímeis para instaurar a confiança, pois a mentira para ter a aparência de verdade precisa da coerência para poder persuadir.

O recurso ao logos, na construção do discurso argumentativo da mentira se operacionaliza, dissimuladamente, buscando a aparência de coerência e logicidade, mas sem compromisso com a verificabilidade da verdade. Sob tal perspectiva, podemos tratar das falácias como base argumentativas das fake news (MELATTI, 2020, p. 195, WARDLE; DERAKSHAM, 2017). As falácias têm apenas aparência de serem argumentos, mas não são. Sua validade é apenas emocional.

Se alguém está motivado a acreditar em algo como verdade, já se encontra de antemão predisposto a aceitá-la, especialmente se a fonte que a enuncia corresponde ao seu gosto, ou procede de alguém porque quem nutre simpatia. Nossos vieses cognitivos nos manipulam, fazendo que aceitemos somente aceitar o que corresponde às nossas crenças, valores e convicções (ZOMPETTI, 2019, p. 142, MCINTYRE, 2018, p. 62).

Nas redes sociais, na maioria das vezes, o modo de raciocínio das pessoas opera motivado pelo preconceito e pelos vieses de confirmação, daí ser muito fácil aceitar um conteúdo mentiroso como se fosse verdade. Há também situações em que mesmo as pessoas sendo confrontadas com fatos e dados objetivos, preferem continuar acreditando naquilo que de antemão já havia aceitado como verdadeiro. As pessoas tendem a acreditar naquilo que querem acreditar (ZOMPETTI, 2019, p. 143; BARTLETT, 2017, p. 97).

As bolhas sociais no ambiente virtual reforçam a aceitação do discurso mentiroso como verdade, alimentam polarizações e fundamentalismos. Em tal ambiente, se constitui um desafio fazer as pessoas enxergarem uma realidade diversa daquela do que elas acreditam (ZOMPETTI, 2019, p. 143). As pessoas enclausuradas em suas bolhas sociais tendem se fecharem cada vez mais em suas convicções, evitando toda e qualquer possibilidade de crítica à sua visão de mundo. Sob tal perspectiva, podemos entender os posicionamentos daqueles que procuram colocar em posição descrédito o saber científico (ZOMPETTI, 2019, p. 148; MCINTYRE, 2018, p. 57).

A construção da mentira tendo o logos como meio de manipulação se articula com ethos, pois, para ser aceita precisa da aquiescência de um auditório e isto depende, igualmente, do caráter 
do orador. A simples demonstração lógica de um argumento não é suficiente para conquistar a adesão dos interlocutores a uma determinada tese. Isso dependerá também da credibilidade de quem o enuncia. É fundamental ainda, atentar para as crenças das pessoas em um auditório para evitar o confronto com estas.

O recurso ao logos também se serve do pathos. O recurso à emoção facilita a conquista do auditório para a aceitação da tese desejada. É comum a associação do pathos, como meio de persuasão, apoiado às falácias como a do "espantalho", da generalização apressada, do apelo ao medo, do falso dilema, da petição de princípio, do apelo ao povo e a de causa e consequência para dar uma aparência de logicidade e coerência ao argumento do mentiroso (ZOMPETTI, 2019, p. 149-157).

\section{CONSIDERAÇÕES FINAIS}

Nosso trabalho esforçou-se em mostrar como se dá o processo retórico na construção da mentira (fake news). Vimos que a mentira que se expressa a partir das fake news é favorecida por uma série de fatores, constituindo-se como um problema a ser enfrentado, sob vários aspectos, especialmente por conta das consequências negativas que delas decorrem. Entre estas, está a sua rápida e descontrolada disseminação e seu potencial de influenciar nos destinos dos indivíduos e da sociedade.

A Retórica, enquanto especulação filosófica, não se contenta apenas em constatar e reconhecer o fenômeno das fake news, quantificá-lo ou explicá-lo, enquanto ciência dos meios de persuasão, esforça para compreender como se dá a construção do discurso argumentativo que se operacionaliza a partir das fake news. Inicialmente, constatamos que o discurso do mentiroso (orador) na elaboração das fake news estabelece-se como o mau uso dos meios de persuasão, constituindo-se como uma forma de manipulação.

O mentiroso (orador) vale-se do instrumental fornecido pela Retórica para compor o seu discurso argumentativo em função da mentira que terá sua expressão nas fake news. Em tal empreendimento o orador tem a seu favor a emergência e o desenvolvimento constante das novas tecnologias de informação e comunicação (redes sociais, algoritmos, big-data, data analytics, web robots e outros), bem como beneficia-se da cultura digital (ambiente digital) que, cada vez mais, se impõe como lugar das interrelações sociais e fonte primária de informação para a maioria das pessoas.

Nosso trabalho moveu-se pelo objetivo de compreender como se dá o processo retórico de construção da mentira a partir das fake news. O sucesso do discurso argumentativo do mentiroso (orador) dependerá da sua habilidade na conquista do auditório ao qual se dirige e o conteúdo da 
mensagem (fake news) que veiculará. Ao orador caberá também o uso dos meios de persuasão (ethos, pathos e logos) que como vimos são potencializados por conta do uso das tecnologias informo-comunicacionais e do ambiente digital no qual as pessoas estão inseridas.

As fake news representam uma ameaça a vida em sociedade, especialmente para a construção da democracia que prima pelo debate, pela pluralidade de opiniões, pela valorização do princípio do contraditório, da transparência, da publicidade, da clareza e da veracidade das informações. As decisões justas e acertadas a serem assumidas em função do bem comum, exige que estas sejam pautadas a partir de critérios de racionalidade, objetividade e veracidade.

A disseminação das fake news impondo-se como uma forma de manipulação, obscurece a verdade e a liberdade dos indivíduos impedindo-os de fazerem escolhas ponderadas. Não é difícil pensar nas consequências acerca de decisões importantes fundamentadas sobre premissas falsas. A pesquisa sobre a temática deve prosseguir, não somente no sentido de verificar a existência do fenômeno das fake news e suas consequências, mas procurar entender como funciona o mecanismo persuasivo delas para poder assim enfrentá-las, pertinentemente.

As fake news devem ser combatidas para evitar os prejuízos que delas podem advir, mas não basta criar os checadores de notícias falsas ou aprovar uma legislação proibindo-as ou condenando-as, pois estas não deixarão de ser produzidas por conta desses impedimentos. Os mentirosos criarão estratégias e se readequarão para continuarem atuando. Já que não é a proibição nem a condenação que irão impedir o surgimento das fake news, elas sempre estarão em nosso meio, por isso defendemos que um dos meios eficazes para combatê-las é a educação do senso crítico de modo a capacitar as pessoas a se oporem a estas.

Por fim, osso trabalho apresentou como se dá o processo retórico na construção da mentira (fake news). Neste sentido propusemos que o conhecimento da Retórica, seus meios e estratégias de persuasão possam contribuir na formação do senso crítico das pessoas, e assim, por analogia, podemos pensar que, se conhecemos o veneno, podemos obter seu antídoto.

\footnotetext{
${ }^{1}$ Conforme Palestra do professor Leandro Karnal: "A divulgação de notícias falsas surgiu bem antes da internet" Disponível em: https://youtu.be/ekmmvqWHTYA. Acesso em: 10 out. 2020.

${ }^{2}$ Derrida cita a versão francesa de um texto de Hanna Arendt Truth and Politics, originariamente, publicado em inglês, na revista norte-americana The New Yorker. O referido texto está integrado no livro da autora La Crise de la Culture, da editora Idées Gallimard, ano 1972, nas páginas 289-290.
} 


\section{REFERÊNCIAS}

AGLANTZAKIS, Vick Mature. Fake news como ameaça à democracia e os meios de controle de sua disseminação. Revista de Teorias da Democracia e Direitos Políticos, v. 6, n. 1, p. 20-37, 2020 .

ALZAMORA, Geane Carvalho; ANDRADE, Luciana. A dinâmica transmídia de fake news conforme a concepção pragmática de verdade. Matrizes, v. 13, n. 1, p. 109-131, 2019.

AMARAL, Inês; SOFIA, J. S. Algoritmos e redes sociais: a propagação de fake news na era da pósverdade. In: FIGUEIRA, João; SANTOS, Sílvio (Ed.). As fake news e a nova ordem (des) informativa na era da pós-verdade: Manipulação, Polarização, Filter Bubbles. Imprensa da Universidade de Coimbra/Coimbra University Press, 2019; n.p.

ARISTÓTELES. Retórica. Edipro. São Paulo, 2013.

BAPTISTA, João. Ethos, pathos e logos. Análise comparativa do processo persuasivo das (fake) news. Eikon - Journal on Semiotics and Culture, v. 1, n. 7, p 43-54, 2020.

BARRETO JUNIOR, Irineu Francisco; PELLIZZARI, Bruno Henrique Miniuchi. Bolhas Sociais e seus efeitos na Sociedade da Informação: ditadura do algoritmo e entropia na Internet. Revista de Direito, Governança e Novas Tecnologias, v. 5, n. 2, p. 57-73, 2019.

BARTLETT, Bruce. The truth matters: A citizen's guide to separating facts from lies and stopping fake news in its tracks. Californie: Ten Speed Press, 2017.

BERGER, Jonah; MILKMAN, Katherine L. What makes online content viral? Journal of marketing research, v. 49, n. 2, p. 192-205, 2012.

BOZDAG, Engin. Bias in algorithmic filtering and personalization. Ethics and information technology, v. 15, n. 3, p. 209-227, 2013.

BRETON, Philippe. A manipulação pela palavra. São Paulo: Loyola, 1999.

DERRIDA, Jacques. História da mentira: prolegômenos. Estudos avançados, v. 10, n. 27, p. 739, 1996.

DURANDIN, Guy. As mentiras na propaganda e na publicidade. São Paulo: JSN, 1997.

GOMES, Sheila Freitas; PENNA, Juliana Coelho Braga de Oliveira; ARROIO, Agnaldo. Fake news Científicas: Percepção, Persuasão e Letramento. Ciência \& Educação (Bauru), v. 26, p. 113, 2020.

GOTTWEIS, Herbert. Rhetoric in policy making: Between logos, ethos, and pathos. In: Handbook of public policy analysis. London/New York: Routledge/CRC Press, 2007, p. 263-276.

GRANT, Arthur J. Ethos, Pathos and Logos: Rhetorical Fixes for an Old Problem: Fake news. In: InSITE 2019: Proceedings of the Informing Science and Information Technology Conference June 30 - July 4, Jerusalem, Israel, 2019, p. 81-91. Disponível em: http://proceedings.informingscience.org/InSITE2019/InSITE19p081-091Grant5114.pdf. Acesso em: 20 jan. 2021. 
GREEN JR, S. E. A rhetorical theory of diffusion. Academy of Management Review, 29 (4), p.653-669, 2004.

HABERMAS, Jürgen. Direito e Democracia: entre facticidade e validade. 2. ed. v.2. Rio de Janeiro: Tempo Brasileiro, 2003.

HOFFELD GROUP. The Difference Between Persuasion \& Manipulation. Disponível em: https://www.hoffeldgroup.com/sales-articles/the-differenc e-between-persuasion-manipulation/ Acesso em: 17 out. 2020.

JUCÁ BENTIVEGNA, Fernando. Fatores de impacto no sucesso do marketing boca a boca on-line. Revista de Administração de Empresas, v. 42, n. 1, p. 1-9, 2002.

LAFER, Celso. A mentira: um capítulo das relações entre a ética e a política. In: LAFER, Celso. Desafios: ética e política. São Paulo: Siciliano, 1995, p. 318-335.

LÉVY, Pierre. A revolução contemporânea em matéria de comunicação. Revista Famecos, v. 5, n. 9, p. 37-49, 1998.

MARQUES, Lidiany Kelly da Silva; VIDIGAL, Frederico. Prosumers e redes sociais como fontes de informação mercadológica: uma análise sob a perspectiva da inteligência competitiva em empresas brasileiras. Transinformação, v. 30, n. 1, p. 1-14, 2018.

MCINTYRE, Lee. Post-truth. Cambridge, MA: MIT Press, 2018.

MEDRÁN, A. No reino da pós-verdade, a irrelevância é o castigo. Revista Uno, São Paulo, n. 27, p. 33-35, 2017. Disponível em: https://tinyurl.com/y9knxgaz. Acesso em: 25 maio 2020.

MELATI, Nathalia. As contribuições da retórica para o estudo das fake news. Verbum. Cadernos de pós-graduação. v. 9, n. 1, p. 187-198, 2020.

MELIM, Maurício José; SCHATTSCHNEIDER, Daniel; DA FONSECA MIRANDA, Ieza Cristina. Bolhas virtuais, velocidade e excesso na rede: um estudo das fake news sob o ponto de vista dos estudos da comunicação. In: VIII Congresso de Professores do Ensino Superior da Rede Sinodal. 2019.

MENDONÇA. A mentira sob o ponto de vista da linguagem: um estudo, uma análise. 2012. Tese (Doutorado) - Curso de Programa de Pós-Graduação em Letras e Linguística, Pontifícia Universidade Católica de Minas Gerais, Belo Horizonte, 2013. Disponível em: http://www1.pucminas.br/imagedb/documento/DOC

_DSC_NOME_ARQUI20170623162712.pdf. Acesso em: 15 out. 2020.

PERELMAN, Chaim e Olbrechts-Tyteca, Lucie. Tratado da argumentação: a nova retórica. São Paulo: Martins Fontes, 2005.

PIAZZA, Tommaso; CROCE, Michel. Epistemologia delle fake news. Sistemi intelligenti, v. 31, n. 3, p. 439-468, 2019.

RASQUEL, Sandra Gomes. A desinformação como estratégia de manipulação e abuso de poder no discurso político. Letras Escreve, v. 8, n. 2, p. 07-32, 2019.

RENNÓ, Aline de Fatima Chiaradia Valadão; SALLES, Atilio Catosso. Discurso e hashtag: diferentes modos de pertencimento no Instagram. Revista DisSoL-Discurso, Sociedade e Linguagem, n. 11, p. 69-90, 2020. 
LEITE, Leonardo Ripoll Tavares; MATOS, José Claudio Morelli. Zumbificação da informação: a desinformação e o caos informacional. Revista Brasileira de Biblioteconomia e Documentação, v. $13,2017.2334-2349, \quad$ p. 2017 Disponível https://febab.emnuvens.com.br/rbbd/article/download/918/941. Acesso em 20 jan. 2021.

SANTAELLA, L. A Pós-Verdade é Verdadeira ou Falsa? São Paulo: Editora Estação das Letras e Cores, 2018.

SEIXAS, Rodrigo. Gosto, logo acredito: o funcionamento cognitivo-argumentativo das fake news. Cadernos de letras da UFF, v. 30, p. 279-295, 2019.

SILVA, Thiago Dias; OLIVEIRA, Luciana Duarte. O Monopólio da Verdade na Era das' Fake news'. Ratio Juris Unaula, v. 14, n. 28, p. 109-126, 2019.

WARDLE, Claire; DERAKHSHAN, Hossein. Information disorder: Toward an interdisciplinary framework for research and policy making. Council of Europe report, v. 27, 2017, p 1-107

ZOMPETTI, Joseph P. The Fallacy of Fake news: Exploring the Commonsensical Argument Appeals of Fake news Rhetoric through a Gramscian Lens. Journal of Contemporary Rhetoric, Vol. 9, No.3/4, pp. 139-159, 2019.

Trabalho recebido em 02 de outubro de 2021

Aceito em 02 de novembro de 2021 